\title{
Index to Volume 40 (2013)
}

No. 1, pp. 1-80; No. 2, pp. 81-153, No. 3, pp. 153-213;

No. 4, pp. 213-282; No. 5, pp. 283-362; No. 6, pp. 363-429.

\section{ALPHABETICAL INDEX}

\section{Articles}

Adler, Melissa, and Joseph T. Tennis. Toward a

Taxonomy of Harm in Knowledge Organization Systems .....266

Almeida, Carlos Cândido de, Mariângela Spotti Lopes

Fujita and Daniela Marjorie dos Reis. Peircean Semiotics and Subject Indexing: Contributions of Speculative

Grammar and Pure Logic. .225

Burnett, Kathleen, and Laurie J. Bonnici. Rhizomes in the iField: What Does it Mean to be an iSchool? 408

Campos, Maria Luiza de Almeida, Maria Luiza Machado Campos, Alberto M. R. Dávila, Hagar Espanha Gomes, Linair Maria Campos, and Laura de Lira e Oliveira. Information Sciences Methodological Aspects Applied to Ontology Reuse Tools: A Study Based on Genomic Annotations in the Domain of Trypanosomatides.

Channon, Martin G.. The Unification of Concept

Representations: An Impetus for Scientific Epistemology ........ 83

Chen, Kuan-nien. Dynamic Subject Numbers Replace Traditional Classification Numbers

De Luca, Ernesto William. Extending the Linked Data

Cloud with Multilingual Lexical Linked Data. .320

Desale, Sanjay K., and Rajendra M. Kumbhar. Research on Automatic Classification of Documents in Library

Environment: A Literature Review. .295

Fedeli, Gian Carlo. Metaphors of Order and Disorder:

From the Tree to the Labyrinth and Beyond

Fóris, Ágota. Network Theory and Terminology

Fox, Melodie J. and Austin Reece. The Impossible Decision: Social Tagging and Derrida's Deconstructed Hospitality......

Galeffi, Agnese. The Spatial Value of Information

Hansson, Joacim. The Materiality of Knowledge

Organization: Epistemology, Metaphors and Society .384

Herre, Heinrich. Formal Ontology and the Foundation of Knowledge Organization.

Hjørland, Birger. Theories of Knowledge Organization - Theories of Knowledge
Hjørland, Birger. User-based and Cognitive Approaches to Knowledge Organization: A Theoretical Analysis of the Research Literature 11

Kleineberg, Michael. The Blind Men and the Elephant: Towards an Organization of Epistemic Contexts.

Lamirel, Jean-Charles. Multi-View Data Analysis and

Concept Extraction Methods for Text 305

López-Huertas, María. Reflexions on Multidimensional Knowledge: Its Influence on the Foundation of Knowledge Organization

Mai, Jens-Erik. Ethics, Values and Morality in

Contemporary Library Classifications.

Marchese, Christine and Richard P. Smiraglia. Boundary Objects: CWA, an HR Firm, and Emergent Vocabulary...

Marcondes, Carlos Henrique. Knowledge Organization and Representation in Digital Environments: Relations Between Ontology and Knowledge Organization .

Marras, Cristina. Structuring Multidisciplinary

Knowledge: Aquatic and Terrestrial Metaphors

Martínez-Ávila, Daniel, and Rosa San Segundo.

Reader-Interest Classification: Concept and

Terminology Historical Overview

Mazzocchi, Fulvio. Images of Thought and Their Relation

to Classification: The Tree and the Net

Moneda Corrochano, Mercedes de la, María

J. López-Huertas and Evaristo Jiménez Contreras.

Spanish Research in Knowledge Organization (2002-2010)..... 28

Oikarinen, Teija, and Terttu Kortelainen. Challenges of Diversity, Consistency, and Globality in Indexing of Local Archeological Artifacts.....

Ridi, Riccardo. Ethical Values for Knowledge Organization..

Rosati, Luca, Antonella Schena, and Rita Massacesi. Childhood and Adolescence Between Past and Present: Using Knowledge Organization to Bridge the Different Channels of a Cultural Institution: The Case of the Istituto degli Innocenti, Fiorenze..

Scaturro, Irene. Faceted Taxonomies for the Performing Arts Domain: The Case of the European Collected Library of Artistic Performance. 
Sienkiewicz, Urszula, and Izabela Kijeńska-Dąbrowska. Knowledge Creation and Commercialization Activities in Polish Public HEUs in the Area of Technical and

Engineering Sciences.

Smiraglia, Richard P.. Is FRBR A Domain? Domain Analysis Applied to the Literature of The FRBR Family of Conceptual Models

Tennis, Joseph T.. Ethos and Ideology of Knowledge Organization: Toward Precepts for an Engaged

Knowledge Organization

Thellefsen, Martin, Torkild Thellefsen and Brent Sørenson.

A Pragmatic Semeiotic Perspective on the Concept

of Information Need and Its Relevance for Knowledge

Organization.

Tredinnick, Luke. Each One of us was Several: Networks,

Rhizomes and Web Organisms

Wu, Yejun. Indexing Historical, Political Cartoons for Retrieval.

\section{Book Reviews}

Kumbhar, Rajendra. Library Classification Trends in the 21st Century. Witney, UK: Chandos Publishing (Oxford) Ltd.: 2012. ISBN: $1843346605,9781843346609$.
Dupré, John. The Disorder of Things: Metaphysical Foundations of the Disunity of Science. Massachusetts; London: Harvard University Press, 1993, 308p. ISBN0-674-21261-4 (Hb); and Human Nature and the Limits of Science. Oxford; New York: Oxford University Press, 2001, 201p. ISBN 0-19-926550-X (Pb)

\section{Reports, Communications, Features, etc.}

Mazzocchi, Fulvio, and Gian Carlo Fedeli. Introduction to the Special Issue: 'Paradigms of Knowledge and Its Organization: The Tree, the Net and Beyond'.

Smiraglia, Richard P.. ISKO 12's Bookshelf-Evolving Intension: An Editorial 3

Smiraglia, Richard P.. Keywords, Indexing, Text Analysis: An Editorial

Szostak, Rick. Speaking Truth to Power in Classification: Response to Fox's Review of My Work; KO 39:4, 300 76

Williamson, Nancy J. Paradigms and Conceptual Systems in Knowledge Organization, the Eleventh International ISKO Conference, Rome, 2010 64

Xiao, Guohua. A Knowledge Classification Model Based on the Relationship Between Science and Human Needs 


\title{
KNOWLEDGE ORGANIZATION
}

\author{
Official Bi-Monthly Journal of the International Society for Knowledge Organization
}

ISSN $0943-7444$

International Journal devoted to Concept Theory, Classification, Indexing and Knowledge Representation

\section{Publisher}

ERGON-Verlag GmbH, Keesburgstr. 11, D-97074 Würzburg Phone: +49 (0)931 280084; FAX +49 (0)931 282872

E-mail: service@ergon-verlag.de; http://www.ergon-verlag.de

\section{Editor-in-chief (Editorial office)}

Dr. Richard P. SMIRAGLIA (Editor-in-Chief), School of Information Studies, University of Wisconsin, Milwaukee, Northwest Quad Building B, 2025 E Newport St., Milwaukee, WI 53211 USA.

E-mail:smiragli@uwm.edu

\section{Instructions for Authors}

Manuscripts should be submitted electronically (in Word format) in English only via email to the editor-in chief and should be accompanied by an indicative abstract of 150 to 200 words. Manuscripts of articles should fall within the range 6,000-10,000 words. Longer manuscripts will be considered on consultation with the editor-in-chief.

A separate title page should include the article title and the author's name, postal address, and E-mail address, if available. Only the title of the article should appear on the first page of the text.

To protect anonymity, the author's name should not appear on the manuscript, and all references in the body of the text and in footnotes that might identify the author to the reviewer should be removed and cited on a separate page.

Criteria for acceptance will be appropriateness to the field of the journal (see Scope and Aims), taking into account the merit of the contents and presentation. The manuscript should be concise and should conform as much as possible to professional standards of English usage and grammar. Manuscripts are received with the understanding that they have not been previously published, are not being submitted for publication elsewhere, and that if the work received official sponsorship, it has been duly released for publication. Submissions are refereed, and authors will usually be notified within 6 to 10 weeks.

The text should be structured by numbered subheadings. It should contain an introduction, giving an overview and stating the purpose, a main body, describing in sufficient detail the materials or methods used and the results or systems developed, and a conclusion or summary.

Footnotes are accepted only in rare cases and should be limited in number; all narration should be included in the text of the article. Paragraphs should include a topic sentence and some developed narrative; a typical paragraph has several sentences. Italics may not be used for emphasis. Em-dashes should not be used as substitutes for commas.

Italics should not be used for emphasis. Em-dashes should be used as substitutes for commas. Paragraphs should include a topic sentence and some developed narrative. A typical paragraph has several sentences.

Reference citations within the text should have the following form: (Author year). For example, (Jones 1990). Specific page numbers are required for quoted material, e.g. (Jones 1990, 100). A citation with two authors would read (Jones and Smith, 1990); three or more authors would be: (Jones et al., 1990). When the author is mentioned in the text, only the date and optional page number should appear in parenthesis e.g. According to Jones (1990), ...
References should be listed alphabetically by author at the end of the article. Author names should be given as found in the sources (not abbreviated). Journal titles should not be abbreviated. Multiple citations to works by the same author should be listed chronologically and should each include the author's name. Articles appearing in the same year should have the following format: "Jones 2005a, Jones 2005b, etc." Issue numbers are given only when a journal volume is not throughpaginated.

Examples:

Dahlberg, Ingetraut. 1978. A referent-oriented, analytical concept theory for INTERCONCEPT. International classification 5: 142-51.

Howarth, Lynne C. 2003. Designing a common namespace for searching metadata-enabled knowledge repositories: an international perspective. Cataloging \& classification quarterly 37n1/2: 173-85.

Pogorelec, Andrej and Šauperl, Alenka. 2006. The alternative model of classification of belles-lettres in libraries. Knowledge organization 33: 204-14.

Schallier, Wouter. 2004. On the razor's edge: between local and overall needs in knowledge organization. In McIlwaine, Ia C. ed., Knowledge organization and the global information society: Proceedings of the Eighth International ISKO Conference 13-16 July 2004 London, UK. Advances in knowledge organization 9. Würzburg: Ergon Verlag, pp. 269-74.

Smiraglia, Richard P. 2001. The nature of 'a work': implications for the organization of knowledge. Lanham, Md.: Scarecrow.

Smiraglia, Richard P. 2005. Instantiation: Toward a theory. In Vaughan, Liwen, ed. Data, information, and knowledge in a networked world; Annual conference of the Canadian Association for Information Science ... London, Ontario, June 2-4 2005. Available http://www.cais-acsi.ca/2005proceedings.htm.

Illustrations should be kept to a necessary minimum and should be embedded within the document. Photographs (including color and halftone) should be scanned with a minimum resolution of $600 \mathrm{dpi}$ and saved as .jpg files. Tables and figures should be embedded within the document. Tables should contain a number and title at the bottom, and all columns and rows should have headings. All illustrations should be cited in the text as Figure 1, Figure 2, etc. or Table 1, Table 2, etc.

The entire manuscript should be double-spaced, including notes and references.

Upon acceptance of a manuscript for publication, authors must provide a wallet-size photo and a one-paragraph biographical sketch (fewer than 100 words). The photograph should be scanned with a minimum resolution of $600 \mathrm{dpi}$ and saved as a .jpg file.

\section{Advertising}

Responsible for advertising: ERGON-Verlag GmbH, Keesburgstr. 11, 97074 Würzburg (Germany).

(C) 2014 by ERGON-Verlag GmbH.

All Rights reserved.

KO is published bi-monthly by ERGON-Verlag GmbH.

- The price for the print version is $€ 259,00 /$ ann. including airmail delivery.

- The price for the print version plus access to the online version (PDF) is $€ 289,00 /$ ann. including airmail delivery. 


\section{KNOWLEDGE ORGANIZATION}

Official Bi-Monthly Journal of the International Society for Knowledge Organization

ISSN $0943-7444$

International Journal devoted to Concept Theory, Classification, Indexing and Knowledge Representation

\section{Scope}

The more scientific data is generated in the impetuous present times, the more ordering energy needs to be expended to control these data in a retrievable fashion. With the abundance of knowledge now available the questions of new solutions to the ordering problem and thus of improved classification systems, methods and procedures have acquired unforeseen significance. For many years now they have been the focus of interest of information scientists the world over.

Until recently, the special literature relevant to classification was published in piecemeal fashion, scattered over the numerous technical journals serving the experts of the various fields such as:

\author{
philosophy and science of science \\ science policy and science organization \\ mathematics, statistics and computer science \\ library and information science \\ archivistics and museology \\ journalism and communication science \\ industrial products and commodity science \\ terminology, lexicography and linguistics
}

Beginning in 1974, KNOWLEDGE ORGANIZATION (formerly INTERNATIONAL CLASSIFICATION) has been serving as a common platform for the discussion of both theoretical background questions and practical application problems in many areas of concern. In each issue experts from many countries comment on questions of an adequate structuring and construction of ordering systems and on the problems of their use in opening the information contents of new literature, of data collections and survey, of tabular works and of other objects of scientific interest. Their contributions have been concerned with

(1) clarifying the theoretical foundations (general ordering theory/ science, theoretical bases of classification, data analysis and reduction)

(2) describing practical operations connected with indexing/classification, as well as applications of classification systems and thesauri, manual and machine indexing

(3) tracing the history of classification knowledge and methodology

(4) discussing questions of education and training in classification

(5) concerning themselves with the problems of terminology in general and with respect to special fields.

\section{Aims}

Thus, KNOWLEDGE ORGANIZATION is a forum for all those interested in the organization of knowledge on a universal or a domainspecific scale, using concept-analytical or concept-synthetical approaches, as well as quantitative and qualitative methodologies. KNOWLEDGE ORGANIZATION also addresses the intellectual and automatic compilation and use of classification systems and thesauri in all fields of knowledge, with special attention being given to the problems of terminology.

KNOWLEDGE ORGANIZATION publishes original articles, reports on conferences and similar communications, as well as book reviews, letters to the editor, and an extensive annotated bibliography of recent classification and indexing literature.

KNOWLEDGE ORGANIZATION should therefore be available at every university and research library of every country, at every information center, at colleges and schools of library and information science, in the hands of everybody interested in the fields mentioned above and thus also at every office for updating information on any topic related to the problems of order in our information-flooded times.

KNOWLEDGE ORGANIZATION was founded in 1973 by an international group of scholars with a consulting board of editors representing the world's regions, the special classification fields, and the subject areas involved. From 1974-1980 it was published by K.G. Saur Verlag, München. Back issues of 1978-1992 are available from ERGONVerlag, too.

As of 1989, KNOWLEDGE ORGANIZATION has become the official organ of the INTERNATIONAL SOCIETY FOR KNOWLEDGE ORGANIZATION (ISKO) and is included for every ISKOmember, personal or institutional in the membership fee (US \$ 55/ US \$110).

Rates: From 2013 on for 6 issues/ann. (including indexes) $€ 229,00$ (forwarding costs included) for the print version resp. $€ 258,00$ for the print version plus access to the online version (PDF). Membership rates see above.

ERGON-Verlag GmbH, Keesburgstr. 11, D-97074 Würzburg; Phone: +49 (0)931 280084; FAX +49 (0)931 282872; E-mail: service@ergon-verlag.de; http://www.ergon-verlag.de

Founded under the title International Classification in 1974 by Dr. Ingetraut Dahlberg, the founding president of ISKO. Dr. Dahlberg served as the journal's editor from 1974 to 1997 , and as its publisher (Indeks Verlag of Frankfurt) from 1981 to 1997.

The contents of the journal are indexed and abstracted in Social Sciences Citation Index, Web of Science, Information Science Abstracts, INSPEC, Library and Information Science Abstracts (LISA), Library, Information Science \& Technology Abstracts (EBSCO), Library Literature and Information Science (Wilson), PASCAL, Referatimyi Zhurnal Informatika, and Sociological Abstracts. 